\title{
POLA MUSIMAN PRODUKSI DAN GUGUR DAUN PADA KLON PB 260 DAN RRIC 100
}

\author{
Seasonal Patterns of Yield and Shed Leaves of PB 260 and RRIC 100 Clones
}

\author{
Tumpal H S SIREGAR
}

\author{
Balai Penelitian Sungei Putih, Pusat Penelitian Karet \\ PO BOX 1415 Medan 20001 Sumatera Utara \\ Email : karetths@yahoo.com
}

Diterima : 24 Juli 2014 / Direvisi : 15 Agustus 2014 / Disetujui : 2 September 2014

\begin{abstract}
Growth and yield are the main agronomic parameters in rubber plant which are influenced by climate variation. Difference climate patterns between north and south equator causes difference peak yield of rubber period of those locations, follows growth and leaf fall period. To determine response of $P B 260$ and RRIC 100 clones toward seasons changing, the research was done in 2011 - 2012 on etalase block, Sungei Putih Experimental Garden, located $3^{\circ}$ north equator. Each clone was arranged in Completed Randomized Design, with 2 replications. Observation results showed that yield (ml latex/tree) in PB 260 had significant correlated with number of shed leaves, Dry Rubber Content (DRC), and rainfall, but it was not significant correlation with soil water content, leaf water content and stem flow. Yield of RRIC 100 had significant correlation with rainfall. Yield patern of those clones showed the lowest yield found in April, and the peak yield in August (PB 260) and September (RRIC 100). Generally, DRC of RRIC 100 was higher than PB 260. Number of shed leaves were higher up to April for PB 260, but RRIC 100 had higher amount of shed leaves in May until August. This research could be indicated that RRIC 100 more withstand to climate changes, mainly rainfall fluctuation. The research result may be used as a guidance that stimulant application could be earlier for PB 260 than RRIC 100, mainly when those clones were managed in north equator.
\end{abstract}

Keywords: Hevea brasiliensis, seasonal, pattern, rainfall, yield, shed leaves

\section{Abstrak}

Pada tanaman karet pertumbuhan dan produksi adalah dua peubah agronomi penting yang sangat dipengaruhi oleh variasi iklim. Pola iklim tahunan yang berbeda pada utara dan selatan khatulistiwa menyebabkan waktu puncak produksi pada kedua kawasan tersebut juga berbeda mengikuti pola pertumbuhan dan gugur daun. Untuk mengetahui respon klon PB 260 dan RRIC 100 terhadap perubahan musim, maka dilakukan penelitian pada tahun 2011 2012 di blok etalase Kebun Percobaan Balai
Penelitian Sungei Putih, yang berada $3^{\circ}$ di utara khatulistiwa. Tiap-tiap klon tersusun menurut Rancangan Acak Lengkap (RAL) dengan 2 ulangan. Hasil penelitian menunjukkan bahwa produksi (ml lateks/tanaman) PB 260 memiliki korelasi yang nyata dengan jumlah daun gugur, Kadar Karet Kering (KKK), dan curah hujan, sedangkan korelasi produksi tidak nyata dengan persentase air tanah, persentase air daun dan jumlah air yang tertampung. Pada RRIC 100 produksi nyata berkorelasi dengan curah hujan. Pengamatan produksi pada kedua klon tersebut menunjukkan bahwa produksi terendah terjadi pada bulan April. Sedangkan produksi tertinggi diperoleh PB 260 pada bulan Agustus dan RRIC 100 pada bulan September. Secara umum, KKK RRIC 100 lebih tinggi dibandingkan PB 260. Klon PB 260 mengalami jumlah daun gugur yang lebih tinggi hingga April, tetapi pada bulan Mei hingga Agustus, RRIC 100 mengalami gugur daun yang lebih tinggi. Penelitian ini menjadi indikasi bahwa RRIC 100 relatif lebih tahan terhadap perubahan lingkungan khususnya curah hujan dibandingkan PB 260. Hasil pengamatan memberi arah penelitian bahwa pada klon PB 260 dapat lebih awal untuk mengaplikasikan stimulan dibandingkan RRIC 100, utamanya bila dikelola di kawasan utara khatulistiwa.

Kata kunci: Hevea brasiliensis, musim, pola musiman, curah hujan, produksi, gugur daun

\section{PENDAHULUAN}

Sejumlah penelitian membuktikan bahwa faktor agroklimat sangat menentukan produksi karet (Hevea brasiliensis Muell Arg.) (Yeang dan Paranjothy, 1982; Roux et al., 2000; Gireesh et al., 2011). Tanaman yang secara siklik periodik mengalami gugur daun, pembentukan daun muda dan daun-daun dewasa menentukan tinggi rendahnya produksi sejalan dengan perubahan musim. Di samping itu, jumlah dan waktu curah hujan juga menjadi faktor yang menentukan 
produksi karena mempengaruhi hari sadap dan lamanya menyadap pada hari sadap (Siregar, 2012). Seperti diketahui, pola musim tahunan yang berbeda pada utara dan selatan khatulistiwa menyebabkan waktu puncak produksi pada kedua kawasan tersebut juga berbeda mengikuti pola pertumbuhan dan gugur daun (Junaidi et al., 2014).

Bila mempertimbangkan faktor klon, pada dasarnya di kawasan yang sama, baik utara maupun selatan khatulistiwa sesungguhnya terdapat perbedaan produksi dan respon tiap klon terhadap pola musim sebagaimana yang disimpulkan Gunasekara et al. (2013) pada penelitian mereka terhadap klon-klon seri RRIC dan RRISL di Sri Lanka. Dengan kata lain, tiap klon pada dasarnya memiliki respon yang berbeda terhadap pola musim. Di Indonesia, penelitian tentang hal yang sama masih sangat terbatas. Pengujian-pengujian klon pada umumnya belum mempertimbangkan respon tiap klon secara spesifik terhadap perubahan musim, meskipun klon-klon unggul sudah ditanam pada berbagai lokasi kebun. Sejauh ini, laporan-laporan kinerja klon-klon yang sedang diuji belum menyajikan adanya dinamika produksi menurut musim (Woelan et al., 2013). Penelitian tersebut dinilai penting karena dalam skala komersial, produksi tanaman sangat dipengaruhi oleh musim. Gireesh et al. (2011) tegas menyatakan bahwa pada tanaman karet pertumbuhan dan produksi adalah dua peubah agronomi penting yang sangat dipengaruhi oleh variasi musim. Masalahnya, selain berhubungan dengan produksi asimilat sebagai resultan dari keberadaan daun di tajuk, produktivitas juga dipengaruhi oleh hari sadap, antara lain dengan pencemaran air yang dapat mengubah Kadar Karet Kering (KKK) sebagai konsekuensi dari aliran air pada batang (stem flow) beberapa saat setelah hujan berhenti.

Tulisan ini menyajikan hasil penelitian tentang dinamika produksi, gugur daun dan sejumlah peubah lainnya menurut bulan pada tahun 2011 - 2012. Penelitian dilakukan terhadap dua klon yang berbeda karakter fisiologinya yakni PB 260 dikenal sebagai quick starter dan RRIC 100 dikenal sebagai slow starter. (Sumarmadji, 2007; Herlinawati dan Kuswanhadi, 2013). Dengan tujuan untuk mengetahui dan membandingkan respon kedua klon menurut bulan, maka penelitian diharapkan menjadi acuan untuk penelitian selanjutnya bahwa dalam pengelolaan panen sesungguhnya diperlukan pendekatan yang lebih rinci meliputi cermatan terhadap periode gugur daun, pertumbuhan daun muda sehingga kebijaksanaan sistem eksploitasi yang diterapkan dapat tepat waktu dan efektif.

\section{BAHAN DAN METODE}

Penelitian ini dilakukan pada tahun 2011 - 2012 di blok etalase Kebun Percobaan Balai Penelitian Sungei Putih, yang berada $3^{\circ}$ di utara khatulistiwa, menggunakan klon PB 260 dan RRIC 100. Tiap-tiap klon tersusun menurut Rancangan Acak Lengkap (RAL) sebanyak 2 ulangan. Catatan curah hujan setiap bulan dikumpulkan pada kurun waktu penelitian. Peubah yang diamati adalah hasil lateks per tanaman (ml lateks/tanaman), jumlah daun gugur setiap bulan (helai), jumlah air yang tertampung pada batang setiap bulan (ml air/tanaman) sebagai stem flow, KKK (\%), persentase air daun dan persentase air tanah setiap bulan. Jumlah daun yang gugur setiap bulan dihitung dengan terlebih dahulu menyiapkan kotak di bawah tanaman berukuran $2 \mathrm{~m} \times 2 \mathrm{~m} \times 0,5 \mathrm{~m}$ (Gambar 1). Daun yang jatuh pada kotak tersebut kemudian dihitung, ditimbang bobot basahnya lalu dikeringkan di dalam oven $70^{\circ} \mathrm{C}$ selama 24 jam, lalu ditimbang kembali untuk menetapkan persentase air daun. Persentase air tanah diketahui dengan mengambil contoh tanah sedalam $0,5 \mathrm{~m}$, kemudian contoh tanah ditimbang dan dikeringkan dalam oven pada suhu dan waktu yang sama dengan uji persentase air daun. Sementara jumlah air yang tertampung di batang diukur dengan terlebih dahulu menyiapkan payung terbalik untuk menghimpun air mengalir ke pipa plastik yang berujung pada jirigen air. Air pada jirigen diukur setiap 3 hari untuk kemudian dikompilasi sebagai air yang tertampung setiap bulan. Kadar Karet Kering diukur dengan mengikuti metode baku, yakni mengambil $5-10 \mathrm{~g}$ contoh lateks, lalu ditimbang dan dikeringkan pada oven $100^{\circ} \mathrm{C}$ untuk kemudian ditimbang kembali. Perbandingan bobot kering dan bobot basah dinyatakan dalam persentase, sebagai KKK. 


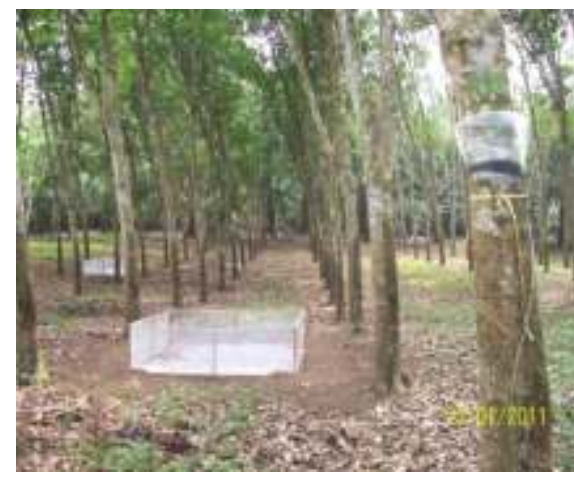

a.Kotak penampung daun Leaf collecting box

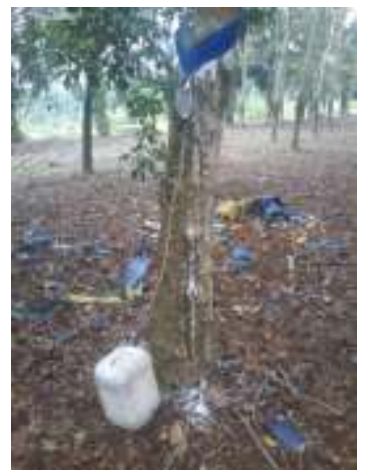

b.Penampung air aliran batang Stem flow water collecting apparatus

Gambar 1. Penampung untuk menghitung daun yang gugur (a) dan penampungan air aliran batang (b) Figure 1. Leaf box for counting shead leaves (a) and water plastic pipe for measuring stem flow (b)

\section{HASIL DAN PEMBAHASAN}

\section{Korelasi Antar Peubah}

Pola curah hujan pada kurun 2011 2012 disajikan pada Gambar 2. Dapat dilihat bahwa curah hujan maksimum terjadi pada semester II, yang dimulai pada bulan Juli. Curah hujan tertinggi terjadi pada bulan Agustus, diikuti dengan Juli dan Oktober. Sebaliknya, curah hujan terendah pada semester I, yakni pada bulan Januari dan April, saat dimana terjadi gugur daun pada kedua klon. Mengingat curah hujan menjadi faktor utama dalam produksi, baik dari aspek fotosintesis maksimum dan kemungkinan tingginya stem flow yang diukur dalam bentuk jumlah air tertampung, maka dilakukan uji korelasi utama yakni curah hujan dengan produksi (ml lateks/tanaman) dan peubah lain yang diamati.

Hasil analisis korelasi antar peubah disajikan pada Tabel 1. Koefisien korelasi ini menunjukkan bahwa terdapat respon yang berbeda dari kedua klon terhadap peubah yang diamati. Pada PB 260 produksi memiliki korelasi yang nyata dengan jumlah daun gugur, KKK, dan curah hujan, sedangkan korelasi produksi tidak nyata korelasinya dengan persentase air tanah, persentase air daun dan jumlah air yang tertampung. Sementara pada RRIC 100 produksi nyata korelasinya dengan curah hujan. Korelasi produksi dengan peubah lainnya tidak nyata. Perbedaan ini terutama disebabkan oleh dua faktor utama dari kedua klon, yakni kapasitas fisiologi sebagai resultan dari keberadaan daun di tajuk. Ketahanan klon RRIC 100 terhadap perubahan lingkungan yang diidentifikasi dari perubahan kadar air tanah serta tipe tajuk yang besar pengaruhnya terhadap jumlah air yang tertampung. Pada sisi lain, Gunasekera et al. (2013) lebih rinci lagi mencermati perbedaan produksi yang meneliti perbedaan klon RRISL 211 dan RRIC 121. Disimpulkan, meskipun RRISL 211 memiliki indeks luas daun 2\% lebih rendah dibandingkan dengan indeks luas daun RRIC 121, tetapi RRISL memiliki kapasitas fotosintesis yang lebih tinggi karena tingginya light saturated maximum photosynthesis. Dengan kata lain, faktor tajuk, keberadaan daun dan kapasitas fotosintesis cenderung lebih berpengaruh pada PB 260 dibandingkan RRIC 100.

\section{Dinamika Produksi}

Pengamatan produksi pada kedua klon tersebut menunjukkan bahwa produksi terendah terjadi pada bulan April. Hal ini sejalan dengan rendahnya curah hujan pada kurun waktu tersebut dan dominannya gugur daun sebagaimana disajikan pada Gambar 3 dan Tabel 2. Sementara produksi tertinggi diperoleh PB 260 pada bulan Agustus dan RRIC 100 pada bulan September. Fenomena ini menunjukkan bahwa PB 260 memiliki respon yang cepat terhadap perubahan di tajuk dalam metabolisme lateks. Setelah gugur daun dan tumbuhnya daun menjadi dewasa, pembentukan asimilat untuk memproduksi 


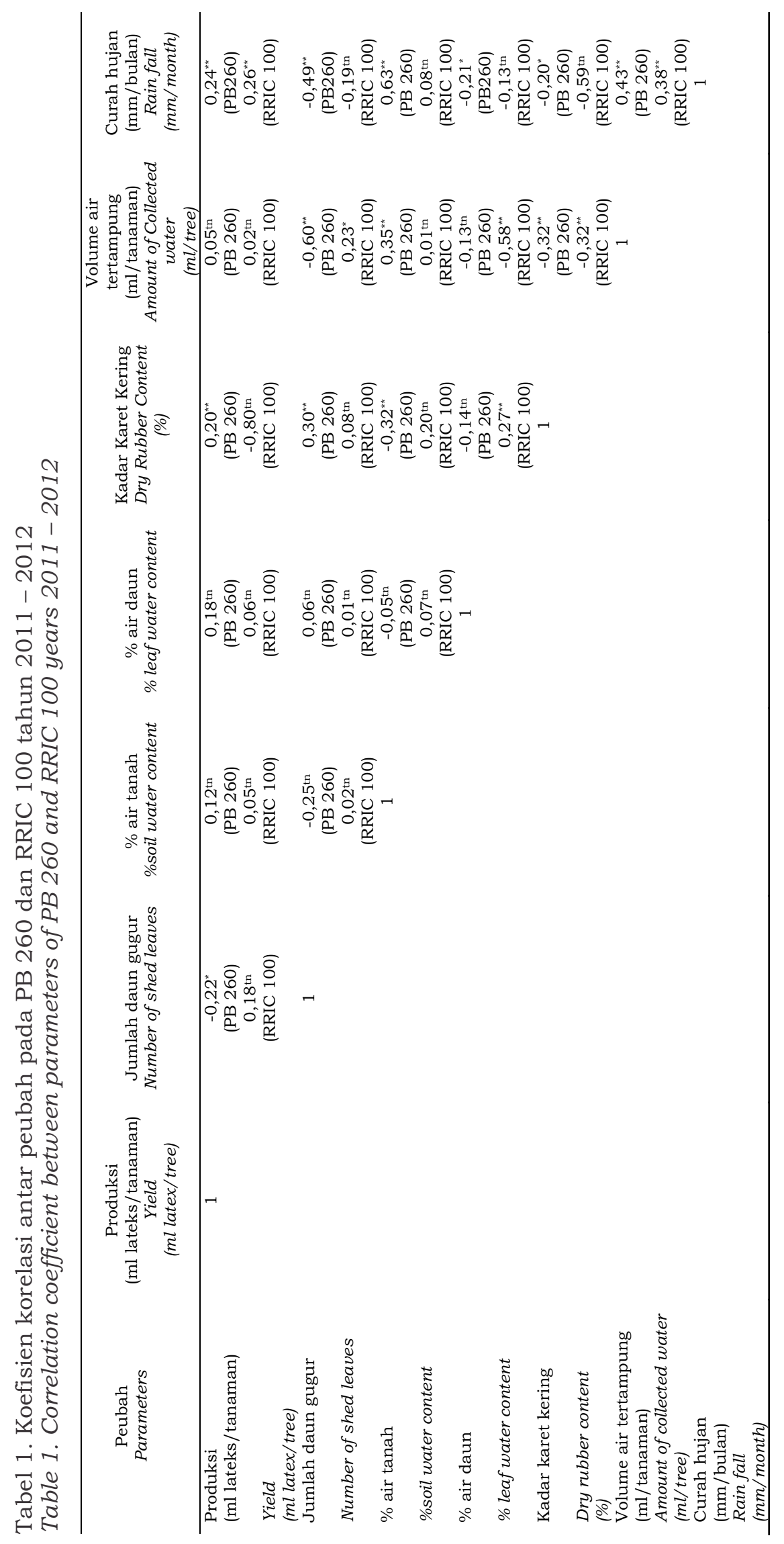




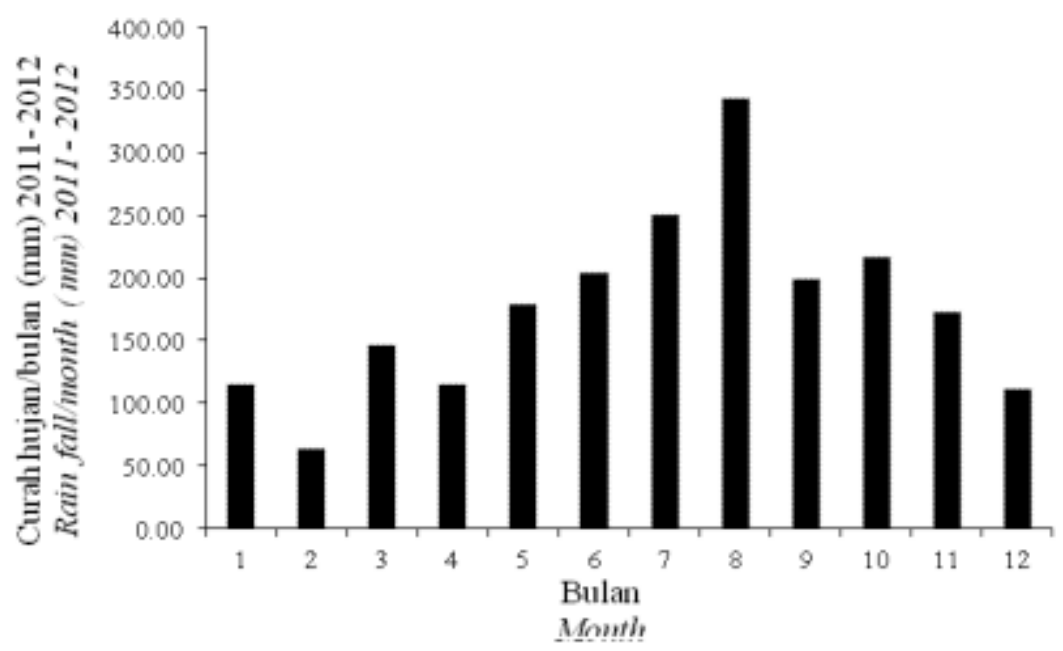

Gambar 2. Curah hujan (mm) bulanan pada $2011-2012$

Figure 2. Mothly rainfall (mm) during $2011-2012$

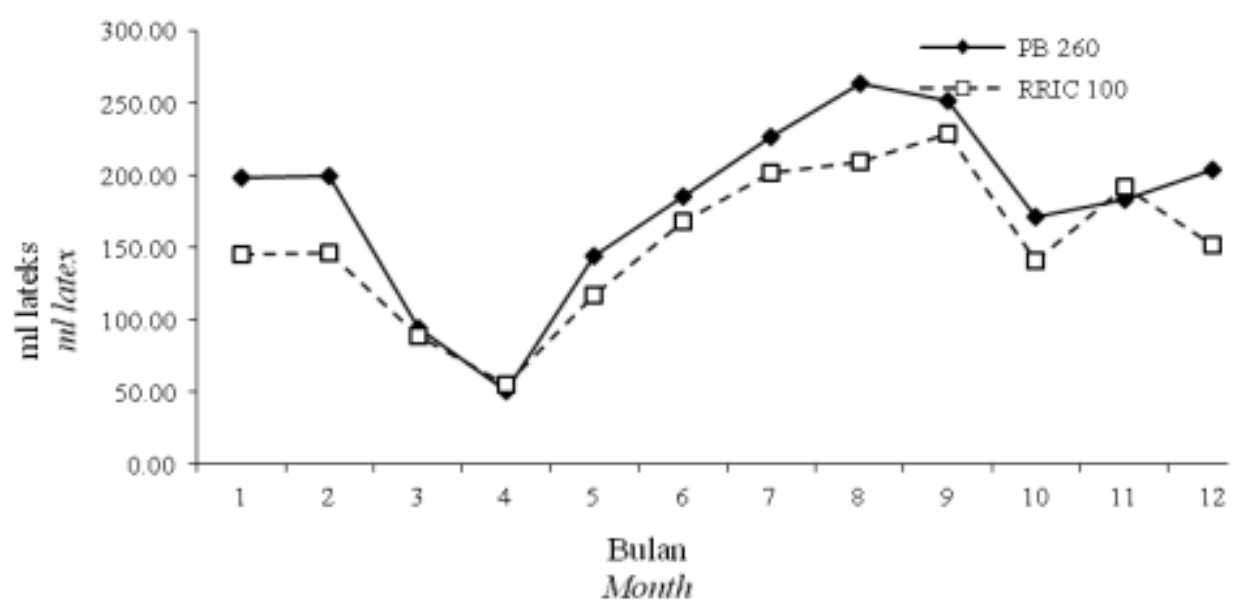

Gambar 3. Produksi lateks (ml/tanaman) menurut bulan pada tahun 2011-2012 Figure 3. Monthly latex yield (ml/tree) in 2011-2012

lateks lebih cepat dibandingkan dengan RRIC 100. Tingginya curah hujan pada bulan Agustus diperkirakan turut memicu tingginya produksi ini. Kshirsagar (2005) dari penelitiannya di India juga menunjukkan besarnya peran curah hujan, keberadaan daun di tajuk dan kapasitas fotosintesis terhadap produksi. Hasil pengamatan ini memberi arah penelitian bahwa pada klon PB 260 dapat lebih awal untuk mengaplikasikan stimulan dibandingkan dengan RRIC 100. Perkiraan awal curah hujan oleh BKMG (2012) menunjukkan bahwa awal musim hujan yang berbeda dalam kisaran minggu di Sumatera Utara dapat menjadi pedoman pertumbuhan daun pada tanaman karet yang sesungguhnya berimplikasi kepada perbedaan usaha peningkatan produksi melalui aplikasi stimulan. Deli Serdang dan sekitarnya diperkirakan mengalami awal musim hujan pada minggu ke-3 bulan Juli, sedangkan kabupaten lain pada minggu ke4 bulan Agustus hingga minggu pertama bulan November.

Meskipun produksi tertinggi pada PB 260 diperoleh pada bulan Agustus, tetapi produksi pada bulan tersebut hanya berbeda nyata dengan produksi yang diperoleh pada bulan Maret dan April. Sementara pada RRIC 100, produksi tertinggi pada bulan September dan Oktober tidak menunjukkan perbedaan yang nyata dengan produksi pada bulan lainnya, sebagaimana yang dapat dilihat pada Tabel 2. 


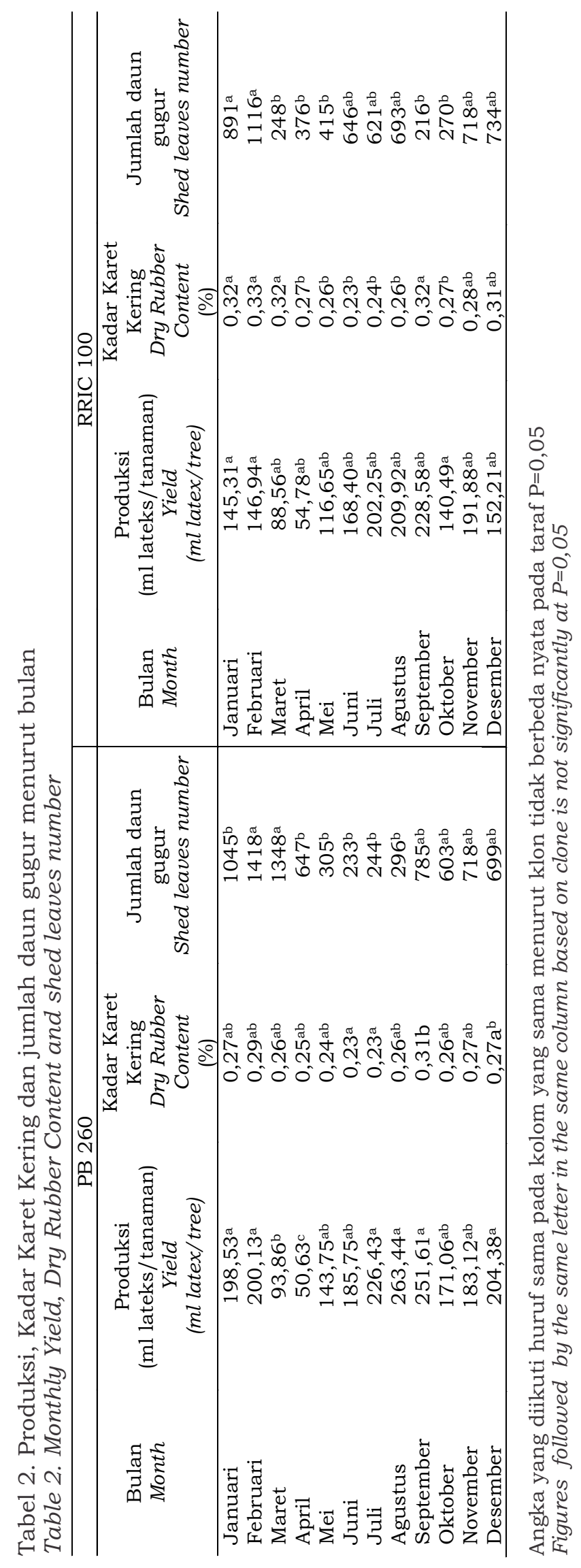




\section{Dinamika Kadar Karet Kering (KKK)}

Sejalan dengan curah hujan dan kondisi tajuk, KKK juga mengalami dinamika sebagaimana disajikan pada Gambar 4. Secara umum, tidak terdapat perbedaan yang nyata dari KKK pada kedua klon, kecuali KKK RRIC 100 pada bulan Februari, meskipun tidak berbeda nyata dengan KKK pada bulan Januari, Maret, September, November, dan Desember (Tabel 2). Sejalan dengan tingginya gugur daun, maka tanaman karet menunjukkan respon peningkatan KKK untuk menata proses fisiologi berjalan terus. Hochachaka dan Samero (1984) menyebutkan respon ini dengan enansiostatik, sehingga tanaman dapat bertahan hidup menunggu ketersediaan air untuk pertumbuhan daun. Terjadinya penurunan KKK pada dua bulan terakhir pada akhir tahun memberi indikasi bahwa akumulasi stem flow dapat mencemari mangkuk lateks. Secara umum, KKK klon RRIC 100 lebih tinggi dibandingkan dengan KKK klon PB 260, yang menjadi indikasi pula bahwa RRIC 100 relatif lebih mampu menyesuaikan proses fisiologi pada perubahan curah hujan maupun kondisi lingkungan tajuk.

\section{Dinamika Gugur Daun}

Pada kedua klon, jumlah daun yang gugur tertinggi terjadi pada bulan Februari dan mengalami penurunan yang tajam pada bulan berikutnya. Pada bulan Februari dan Januari curah hujan terendah yang berkonsekuensi kepada tingginya jumlah daun yang gugur. Bila dibandingkan, maka PB 260 mengalami jumlah daun gugur yang lebih tinggi hingga April, tetapi pada bulan Mei hingga Agustus, RRIC 100 mengalami gugur daun yang lebih tinggi (Gambar 5). Terdapat dua kemungkinan yang menyebabkan perbedaan ini. Pertama, tajuk pada PB 260 yang umumnya lebih tebal dan lebat berkonsekuensi kepada jumlah daun yang gugur lebih banyak. Sebaliknya, tajuk RRIC 100 yang relatif lebih tipis berkonsekuensi kepada jumlah daun yang gugur lebih sedikit. Kedua, PB 260 memiliki respon yang cepat terhadap perubahan curah hujan bila dibandingkan dengan RRIC 100. Dengan kata lain, respon homeostatik pada PB 260 lebih cepat bila dibandingkan dengan RRIC 100. Sekali lagi, peubah ini menjadi indikasi bahwa RRIC 100 relatif lebih tahan terhadap perubahan lingkungan khususnya curah hujan.

Meskipun jumlah daun yang gugur terbanyak pada bulan Februari, tetapi pada PB 260, jumlah daun gugur pada bulan tersebut tidak berbeda nyata dengan jumlah daun yang gugur pada bulan September, Oktober, November dan Desember. Kemungkinan besar, jumlah daun yang gugur pada akhir tahun sudah berkombinasi dengan umur daun. Sementara pada RRIC 100, jumlah daun terbanyak gugur pada bulan Februari hanya berbeda nyata dengan jumlah daun yang gugur pada bulan April, Mei dan September. Hasil pengamatan ini memberi indikasi bahwa RRIC 100 lebih stabil dalam respon perubahan curah hujan (Tabel 2).

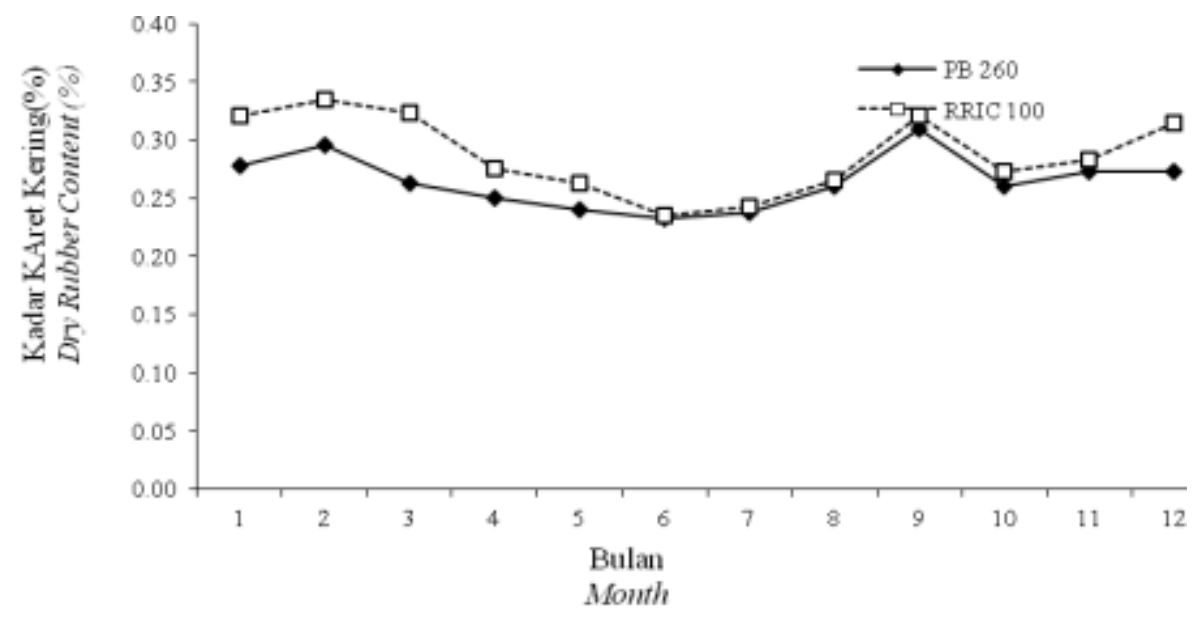

Gambar 4. Kadar Karet Kering (\%) bulanan pada 2011 - 2012

Figure 4. Monthly Dry Rubber Content (\%) during $2011-2012$ 


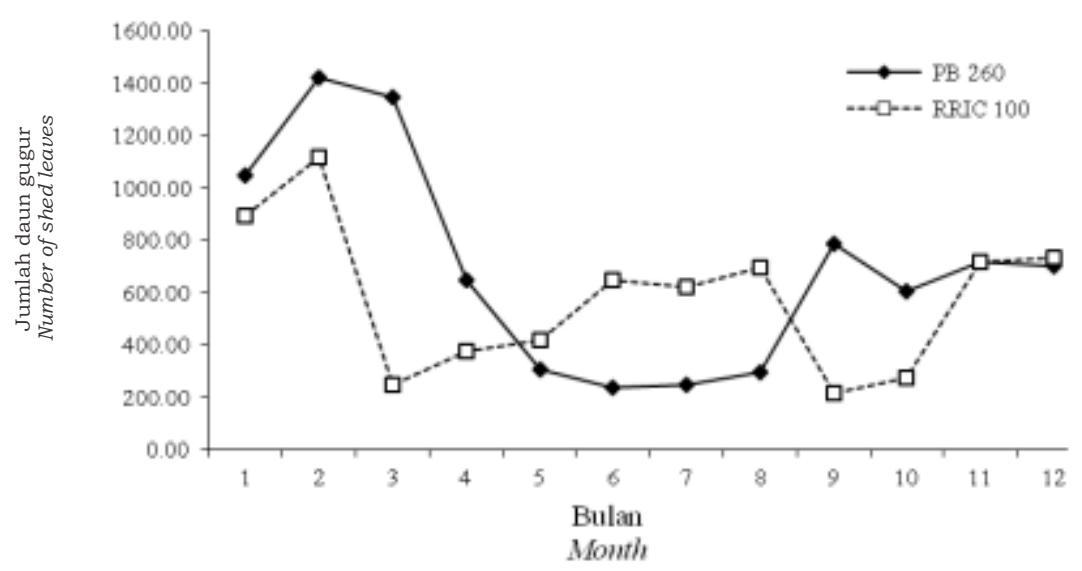

Gambar 5. Jumlah gugur daun (helai) bulanan pada $2011-2012$

Figure 5. Mounthly Number of shed leaves during $2011-2012$

\section{Dinamika Stem Flow}

Sejalan dengan tipisnya tajuk sebagai akibat dari banyaknya daun yang gugur, maka pada bulan April dan Mei volume aliran batang yang tertampung lebih tinggi bila dibandingkan dengan awal tahun. Dengan kata lain, meskipun dengan curah hujan yang tidak tinggi, dominan air hujan mengalir pada batang, sebagaimana yang dapat dilihat pada Gambar 6. Sejalan dengan peningkatan curah hujan, adanya pertumbuhan daun pada bulan Juli berkonsekuensi kepada penurunan jumlah air yang terbatas dan pada bulan Oktober, November dan Desember terjadi penurunan sejalan dengan dominasi daun dewasa dan tajuk pada kondisi yang maksimal. Korelasi antara volume aliran batang yang tertampung dengan curah hujan nyata pada kedua klon, sebagaimana disajikan pada Tabel 1.

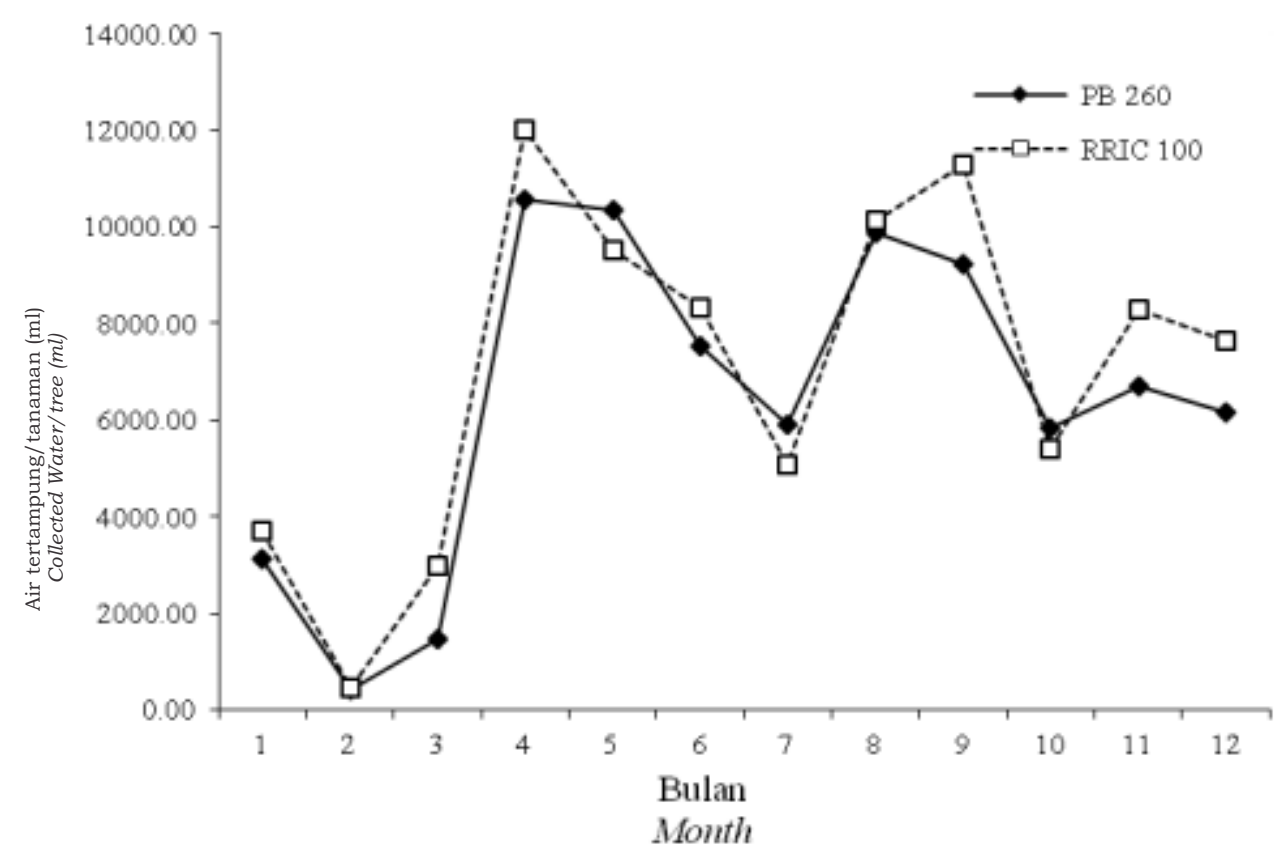

Gambar 6. Air aliran batang tertampung per tanaman (ml) per bulan pada $2011-2012$

Figure 6. Mounthly collected water of stem flow per tree (ml) during $2011-2012$ 


\section{KESIMPULAN}

Dari hasil penelitian ini disimpulkan bahwa dinamika produksi dan gugur daun mengikuti pola curah hujan. Koefisien korelasi menunjukkan bahwa terdapat respon yang berbeda dari kedua klon terhadap peubah yang diamati. Pada PB 260 produksi memiliki korelasi yang nyata dengan jumlah daun gugur, KKK, dan curah hujan, sedangkan produksi tidak berkorelasi nyata dengan persentase air tanah, persentase air daun dan volume air yang tertampung. Sementara pada RRIC 100 produksi nyata berkorelasi dengan pada curah hujan. Pengamatan produksi pada kedua klon tersebut menunjukkan bahwa produksi terendah diperoleh pada bulan April, sedangkan produksi tertinggi klon PB 260 terjadi pada bulan Agustus dan RRIC 100 pada bulan September. Secara umum, KKK RRIC 100 lebih tinggi dibandingkan dengan KKK klon PB 260. Klon PB 260 mengalami jumlah daun gugur yang lebih banyak hingga April, tetapi pada bulan Mei hingga Agustus, RRIC 100 mengalami gugur daun yang lebih tinggi. Penelitian ini menjadi indikasi bahwa RRIC 100 relatif lebih tahan terhadap perubahan lingkungan khususnya curah hujan bila dibandingkan PB 260. Hasil pengamatan ini memberi arah penelitian bahwa pada klon PB 260 dapat lebih awal untuk mengaplikasikan stimulan dibandingkan dengan RRIC 100, utamanya bila dikelola di kawasan utara khatulistiwa.

\section{DAFTAR PUSTAKA}

Badan Klimatologi Meteorologi dan Geofisika. 2012. Peta Prakiraan Awal Musim Hujan 2012/2012 Zona Musim di Aceh dan Sumatera Utara. BMKG, Jakarta.

Gireesh, T., S. Raj., Kavita, K. Midin., and V. C. Mercykutty. 2011. Rubber Yield of Certain Clones of Hevea Brasiliensis and Its Relationship With Climate Variables. Nat.Rubb Res. 24(1): 54 60.
Gunasekera, H. K. L. K., W. A. J. M. De Costas and A. Nugawela. 2013. Canopy Photosynthetic Capacity and Light Reponse Parameters of Rubber Hevea Brasiliensis With Reference to Exploitation. Curr.Agric.Res.J. 1(1) : 112

Herlinawati, E., dan Kuswanhadi. 2013. Aktivitas Metabolisme Beberapa Klon Karet Pada Berbagai Frekuensi Sadap dan Stimulai. Jurnal Penelitian Karet 31(2): $110-116$.

Hochachaka dan Samero. 1984. Biochemical Adaptation. Princetown University Press, New Yersey.

Junaidi, T. H. S. Siregar dan Y. R. Sembiring. 2014. Pemangaat Informasi Iklim Untuk Perkebunan Karet. Makalah pada Penyuluhan Pengamatan Pos Kerjasama Sumatera Utara. BKMG WilayahI. Sumut.

Kshirsagar, P. J. 2005. The Latex Yield of Hevea in Relation to Climatic Factors. India Agriculture Scientist Community, India.

Roux, Y. Lee., E. Ehabe., J. S. Beuve., J. Nkengafac., J. Nkeng., F. Ngolemasango., and S. Gobina. 2000. Seasonal and Clonal Variation in Latex and Raw Rubber of Hevea Brasiliensis. J.Rubb.Res. 3(3): $142-156$.

Siregar, T. H. S. 2012. Pemanfaatan Data Iklim Untuk Meningkatkan Produksi Perkebunan : Kasus Perkebunan Karet. Makalah pada Penyuluhan Pengamat Cuaca/Iklim BMKG Stasiun Klimatologi Kelas I Sampali. Medan.

Sumarmadji. 2007. Optimized Exploitation System for Various Rubber Clones. Prosc. Int. Rubb. Conf. and Exhibition. Nusa Dua, Bali, 13-15 Juni. IRRIIRRDB.: 169 - 183 .

Woelan, S., Sayurandi, dan S. A. Pasaribu. 2013. Karakter Fisiologi, Anatomi, Pertumbuhan dan Hasil Lateks Klon IRR Seri 300. Jurnal Penelitian Karet 31(1): 1-12. 
Yeang, H. Y and K. Paranjothy. 1982. Some Primary Determination of Seasonal Yield Variation in Clone RRIM 623. J.Rubb.Res.Inst.Malaysia 30(3): 131 147. 